\title{
9
}

\section{SOLID WASTE MANAGEMENT INTERNATIONAL PERSPECTIVES}

\author{
Håkan Rylander \\ President ISWA \\ Managing Director of SYSAV, \\ Southwest Scania Solid Waste Company \\ Sweden
}

\section{ABSTRACT}

Solid Waste Management is from many perspectives an international mission. Pollutants and emissions do not know of any boarders, they move from one country to another causing problems. We are all involved in the important task to protect the environment from these emissions - emissions coming from different products which finally have turned into waste. Wastes are simply discarded products and the design of a product can have a very significant impact on the nature of the waste that is produced. Different products are spread all over the world, finally ending up as waste, thus contributing to the negative impact on the environment if not handled in a proper way. It is only by working together from an international perspective as we can influence the producers to take their responsibility for a product throughout its entire life cycle and as we can develop ways of handling produced waste in such a way that the transboundary movement of emissions and the negative impact on the environment is minimized.

Any vision, any outlook and any discussion of the future solid waste management must be based upon Agenda 21, adopted at the UN Conference on "Environment and Development" in Rio de Janeiro, 1992. The International Conferences, Habitat I and Habitat II following of Agenda 21 have clearly showed the necessity of stressing a continously developing of an improved and acceptable solid waste management, especially in urbanized and over-crowded city areas. The problem of getting a hygienical and environmentally safe solid waste management is to a very large extent a problem of the large city areas. 
As waste management is a worldwide problem - with very much the same problems in different countries - there also is a need of exchanging information, experiences, know-how and results from $\mathrm{R} \& \mathrm{D}$ and different projects.

From an International Perspective the establishing of a well functioning network is extremely important.

\section{INTRODUCTION}

Agenda 21 addresses the pressing environmental problems of today and aims of preparing the world for the environmental challenges of the 21 st century. In several chapters Agenda 21 deals explicitly with waste management. It holds out the hope that sustainable development, which integrates environmental protection and economic development, will lead to the fulfillment of basic needs, improved living standards for all, better protected and managed ecosystems and a safer, more prosperous future. The term sustainable development was first introduced in the publication "Our common Future" in 1987, issued by the World Commission on Environment and Development. In the report, sustainable development is defined as development that meets the needs of the present without compromising the ability of future generations to meet with their own needs.

The International Solid Waste Association, ISWA, established in 1994 five different goals for its own future activities and to fulfill its undertakings among others in accordance with the aims of Agenda 21.

- The five ISWA-goals are:

- Protect Human Health, Natural Resources and the Environment

- Provide information

- Promote Research and Development, Education and Training

- Influence Policies by Expert Opinion

- Serve the Membership.

The first goal, which is the most importing goal to be reached worldwide, includes a number of strategies and activities. In the short perspective it is most important, not to say necessary, to increase worldwide the knowledge and awareness about the relationship between correct and good solid waste management and the protection of human health, natural resources and the environment. If we fail to bring out this knowledge and awareness an uncontrolled solid waste disposal will result in rapidly increasing damage of the environment, hygienic threats and waste of non-renewable resources. In a longer perspective the strategy must include, not only management of waste as it is, but also pre-production assessment of life cycles of materials and products, including their end use or other final disposition.

The relationship between correct and good solid waste management and the protection of human health, natural resources and the environment requires a continously upgrading solid waste management. In many places in the world today that starts with a controlled sanitary landfilling, developing into a more ad- 
vanced system with source separation of hazardous products and recyclable products and a more advanced combination for the recovery and final disposal of waste. It is necessary to present requirements within the solid waste field to promote high environmental practices, in such a way also continously upgrading solid waste management. One way of upgrading solid waste management and promoting high environmental practices is by presenting good examples and models of how a well functioning solid waste management in different situations results in the protection of human health, natural resources and the environment. Of course, it is not possible to implement such examples and models without adopting them to the local, regonal or national conditions. However, an increased international exchange of models, examples and experiences will contribute to a faster development of a correct and good solid waste management.

Establishing National Associations in different countries within the field of solid waste management will facilitate the exchange of information and experiences on a national level as well as on an international level.

Based upon Agenda 21, the European Union Strategy for Waste Management, the above mentioned ISWA-goals and other international declarations, solid waste management worldwide step by step must be based upon the ambition of:

Waste Prevention, Waste Reduction and less Hazardous Content in Products and in Waste

- The Producer's Responsibility

- Control of Tranboundary Waste Shipment

- Rigorous Enforcement of Environmental Laws and Standards

- Establishment of Environmentally and Economically Sound Recycling, Treatment and Disposal using a Combination of Methods

- Recycling and Recovery

- Thermal Treatment with Energy Recovery

- Biological Treatment

- Landfilling

\section{WASTE PREVENTION, REDUCTION AND LESS HAZARDOUS CONTENT IN PRODUCTS AND WASTE}

The EU Strategy settles, as regards the prevention option, the following measures to be particularly developed:

- Promotion of clean technologies and products

- The establishment of technical standards and wide rules to limit the presence of certain dangerous substances in products

- The promotion of reuse and recycling schemes

- The appropriate use of economic instruments, ecobalances, eco-audit schemes, etc. 
The environmental impact of a product or an installation is not limited to the generation of waste. Therefore the most appropriate management option regarding a specific type of material object can only be found by evaluating a specific item's impact on the environment during its whole life cycle. The burden on the environment must be determined by the use of "cradle to grave approaches", i.e. by assessing the impact of the extraction of virgin raw materials, through processing, manufacturing, transporting, using and handling as waste. The aim of such an approach is to conserve raw materials and energy on the one hand, and to reduce the generation of waste, in particular its hazardousness, on the other hand (2).

An important element for promoting the prevention of waste is certainly the price element. Where the price of natural resources is low, more waste is generated; also where the price of waste disposal is significant, waste generators are likely to avoid these costs by making efforts to reduce the generation of wastes. Economic instruments such as charging products which are neither reusable nor recyclable, are methods which are used in some countries in order to orient consumers' peference to other products.

The key objective of any waste policy based on the precautionary and preventive principle must be to prevent the generation of waste, and furthermore to reduce the content of hazardous materials in waste (2).

Waste prevention should be the comerstone of sustainable waste management policies worldwide (3).

\section{THE PRODUCER'S RESPONSIBILITY}

As said so many times - emissions, pollutants and products don't know of any boarders. We must all world-wide work together in order to avoid or minimize the negative impacts on nature of different discarded products. It is important to understand that wastes are simply discarded products and the design of a product can have a very significant impact on the nature of the waste which is discarded. Recycling and reuse can be enhanced by designing products so that components and materials can be easily separated, by eliminating contaminating materials that inhibit recycling, and by using more recycled materials in the original products (1).

A preventive waste policy aiming at preventing generation of waste must begin with the product and production process. Waste management concerns have to be fully taken into account from the product's design or conception phase. To be effective, it implies that action is necessary at all stages of a product's lifecycle from production, through use to collection, re-use, recycling and final disposal (2). The European Union stresses this approach to the waste problem on its present review of the Community Strategy for Waste Management. It is of course not only an European approach to the waste problem but also a Global one.

The Producer's Responsibility involves taking responsibility for a product throughout its entire life cycle including responsibility of management of wastes 
after the product is dicarded. While persons responsible for waste management can identify desirable changes in products from a solid waste management perspective, responsibility for making such changes lies with product manufacturers (1). Considering the life cycle of a product from manufacture until the end of its useful life, material suppliers, trade, consumers and public authorities share specific waste management responsibilities. However, it is the product manufacturer who often has a predominant role. The manufacturer is the one to take the key decisions conceming his product, such as design, conception, use of specific materials, composition of the product and finally its marketing. The manufacturer is therefore able to provide the means not only to avoid waste by a considered utilization of natural resources and of non - hazardous materials, but also for proper re-use, including marking, labelling, the issue of instructions for use etc. His active involvement in the product's sound treatment once it becomes waste should not be excluded (2). This especially goes for his economical responsibility. On the other hand it is very important not to exclude all the professionals in solid waste management, with all their competence and experience, from the collection, transportation of products aimed for recycling. There is a tendency in many countries worldwide to split the two groups - the Producers and the Professionals within Waste Management, not using their combined competence and experience in solving a difficult problem. On the contrary, there should be a close cooperation between the two groups in order to minimize especially the use of non-renewable resources and the negative impact on the environment from discarded products.

\section{THE CLOSED CYCLE SOCIETY}

The basic principles from an international perspective must be to close the life cycle of substances, components and products from their production through their useful life until they become waste. We are beginning to see the implementation of this concept, "The Closed Cycle Society" or "The Eco - Cycle Society", in laws that are being passed in various countries requiring manufacturers to take back discarded products - packagings, demolition waste, electronicle waste, old tyres, scrap vehicles etc - for reuse or recycling. "The Closed Cycle Society" includes a number of different actions - reuse, recycling, energy recovery, biological recirculation of organic products, etc. (See Enclosure no 1).

\section{THE SHIPMENT OF WASTE}

The most anxious problem and probably the most difficult one within solid waste management is to take care of hazardous waste produced by the industry. Every manufacturer, every single country must be aware of the problems and dangers to human health and the environment that can be caused by different chemicals and hazardous wastes. It is rather easy to implement the Producer's Responsibility on rather harmless packagings. The real effort should be put on establishing the principle in practice on Hazardous Products, before being discarded as waste. 
That's the real challenge - for the producers and for the International Society. From an International Perspective we will all gain from it.

Agenda 21 points out that the illegal traffic of hazardous waste may cause serious threats to human health and the environment and impose a special burden on the countries that receive such shipment. The prevention of illegal traffic in hazardous waste will benefit the environment and public health in all countries.

Wide - scale ratification and implementation of the Basel Convention is essential to control international shipment of hazardous waste and assure their proper treatment and disposal.

Recognizing that simple elimination of transport of wastes is not sufficient for environmental protection, the Basel Convention also encourages efforts to reduce waste generation, develop national self-sufficiency in hazardous waste disposal, and ensure environmentally sound treatment and disposal systems (1).

\section{ENFORCEMENT OF ENVIRONMENTAL LAWS AND STANDARDS}

The introduction and establishment of environmental laws, standards, ordinances and licenses is a necessary and very important step in every country worldwide, in order to protect human health, natural resources and the environment. In countries where such legislative programmes have been established there is a significant improvement in waste management. On the other hand in countries, where such programmes still are missing wastes continue to be handled in a very poor way, dumped indiscriminately or disposed of improperly, leading to environmental damage and health exposure (1).

Environmental legislation must be rigorously enforced in order to assure the public that solid waste systems are operated in ways that protect human health and the environment (1). The EU-Commission is convinced that only very strict environmental standards for all waste management installations can help to overcome the far-spread concern of the population which finds its concrete application in the expression of NIMBY ("Not In My Back Yard").

\section{ENVIRONMENTALLY SOUND TREATMENT AND DISPOSAL - A COMBINATION OF METHODS}

Even with maximum fesible rates of waste reduction, reuse and recycling, there will still be a need for waste treatment and landfilling. The standard of waste treatment and landfilling is rapidly improving and there are today technologies available to treat and dispose of wastes in an environmentally sound manner. For example today's waste incineration in many countries meets with very tough environmental requirements. Many plants are equipped with highly efficient air pollution control systems. In many countries, especially in Northern Europe, the produced energy is recovered as heat and electricity. The method could be used 
worldwide for hygienic reasons, for reducing the volume of waste and for recovery of energy.

Biological treatment of easily degradable organic waste is used worldwide - in composting or anaerobic digestion. Based upon negative experiences in the past, tough standards and the market's requirement we all today realize that an acceptable end product / output only can be produced out of a clean in-put. The production of an acceptable compost or residue out of digestion can only be reached from an in-put of a organic waste, not mixed with other wastes or fractions. This principle has been well-known in many countries for a long time and is now that well-spread over the world that we see a rapid development of biological waste treatment.

Today's modern landfills meet with similar tough standards, most of them are equipped with leachate collection systems, with gas collection systems with energy recovery, groundwater monitoring, closure and post-closure care and with a number of recycling activities going on at the landfills.

The objective is to ensure that landfilling, when used is performed in a manner that greatly reduces the chance of environmental degradation and also ensure that any release that does occur is quickly detected and corrected (1).

Solid waste managemant in practice must be based on integrated systems with a combination of many different methods. There should not be any contradiction between the different methods - instead they should be regarded as complementing each other. On a fundamental level, in order to introduce a functioning solid waste management, the organizing of collection and transportation of different wastes and a proper landfilling carried out in an environmentally correct way is the first, very important step. With increasing demands of the saving of non-renewable natural resources, increased recycling, an even better environmental protection and an upgraded solid waste management emphasis could be placed on the following principles for the future handling of waste:

- Recovery and recycling of materials, involving direct action by residents and industries, in cooperation with those given the responsibility for the recycling, collection and transportation of different materials and products.

- An increased and improved collection, transportation, recycling, treatment and final disposal of hazardous waste.

- Increased utilization of the material and energy resources in industrial waste. The conservation of resources should mainly take place within the industry, by waste minimization and by material recovery and recycling.

- Thermal treatment of waste, with energy recovery - for heat, cooling and power production.

- Utilization of easy - biodegradable organic waste for composting or anaerobic digestion with gas production.

- Landfilling, which always will be needed regardless of other methods utilized, for non-recyclable materials, residues from other treatment etc. 
The choice of method or combination of methods must be based upon a number of conditions - the market for different recycled products, the possibility of using produced energy and compost, the area available for landfilling, the population density etc. It is not possible from an International Perspective to give an over-all recommendation or solution on the waste problem. The decision must be based upon the local, regional and national conditions, but most probably some of the above mentioned methods should be used in combination.

\section{INFORMATION, TRAINING}

As waste management is a worldwide problem - with very much the same problems in different countries and with emissions, pollutions and products spread across the boarders - there also is a need of exchanging information, experiences, know-how and results from $\mathrm{R} \& \mathrm{D}$ and different projects. There is also a need for training courses. ISWA is in a position for providing information and training - through its journals, magazines, publications, proceedings and through its working groups. ISWA already offers training courses within sanitary landfilling through the Landfilling Working Group, especially to the developing countries in such a way Upgrading Solid Waste Management worldwide. Also other working groups may in the future initiate and offer training programmes within their special fields.

From an International Perspective the establishing of a well functioning network is extremely important. With a functioning network all the above mentioned goals much easier will be reached.

\section{SUMMARY}

ISWA can play a key role in defining and identifying waste management policies and practices which are consistent with sustainable development, and in creating awareness and encouraging implementation of these pratices throughout the World.

More than ever before, waste management policy makers need sound and reliable information on the technical performance, environmental impact and cost of waste collection, recycling, treatment and disposal systems. ISWA is in a unique position to provide this information. The eleven ISWA Working Groups are the platform for cooperation on projects in specific areas at international level, and they are the scientific and technical core of ISWA. ISWA presently has Working Groups in the fields of Biological Treatment, Collection and Transport Technologies, Hazardous Waste, Health Care Waste, Legal Issues, Social Issues, Recycling \& Waste Minimisation, Sanitary Landfilling, Sewage \& Water Works Sludge, Thermal Treatment and a specilised regional group dealing with European Union issues. A Working Group dealing with Developing Countries issues is presently being set up. 
As a response to the growing need for exchange of information on waste management, ISWA has recently taken the initiative to establish a network for waste management professionals in developing and industrialising countries. The network currently contains approximately 1000 contacts in 80 countries. The participants are professionals in waste management. All participants have been classified as to their areas of expertise and their specific branch of the solid waste field. The main purpose of the network is to provide a forum for exchange of information but may also be utilised later for more focused projects.

There remains a tremendous opportunity to improve waste management practices. However, in order to accomplish this it will be necessary for waste professionals to increase their technical and engineering skills. ISWA through its professional development programmes, can play an important role in helping waste management professionals develop broadly based strategic initiatives to bring about continous improvement in waste management practices which are consistent with sustainable development.

\section{REFERENCES}

1. "Waste Management Principles Consistent with Sustainable Development", 1994, John H. Skinner, President, ISWA.

2. "Communication from the Commission to the Council and the European Parlament on the review of the Community Strategy for Waste Management" European Union. Draft, 22 April 1996. 